\title{
ЯЗЫКОЗНАНИЕ
}

UDC 811.113.4+81'3

Yury Kuzmenko

Institute for Linguistic Studies. Russian Academy of Sciences

\section{SHORTENING OF LONG STRESSED VOWELS IN FRISIAN*}

For citation: Kuzmenko Yu. Shortening of long stressed vowels in Frisian. Scandinavian Philology, 2019, vol. 17, issue 1, pp. 5-21. https://doi.org/10.21638/11701/spbu21.2019.101

In contrast to the traditional treatment of Frisian vowel quantity as phonologically relevant, it is considered to be predictable and dependent on the type of contact (long vowel $=$ open contact vs short vowel $=$ close contact). The replacement of an open contact by a close one in Frisian started in the late 17th c. and has been going on until now. Most disyllabic words in Frisian as well as in the other Germanic languages consist of a root and a suffix. As a result of the change of the contact type (open > close) and, consequently, vowel shortening, the number of words with coinciding syllable and morpheme boundaries has increased. This is similar to the change that has taken place in English and Danish, but in Frisian it has some peculiarities, such as vowel shortening in disyllabic words with suffixes and a new Frisian breaking (the development of short rising diphthongs in close contact words from long falling diphthongs in open contact words). These peculiarities distinguish Frisian from the other West Germanic languages but they are typical of the Jutlandic Danish dialects where the new breaking occurs in the same types of words. In this process, short rising diphthongs, the result of the Old Frisian and Old Scandinavian breaking, may have served as a model in the formation of the new short rising diphthongs in Frisian and Jutlandic Danish. In this context, this change may have been a consequence of language contact. The replacement of close contact by open contact in disyllabic words in the language of the younger Frisian generation can be accounted for by the influence of Dutch, Low- and High German (the Frisian youngsters even in the Netherlands not to mention Germany having

* The research was supported by the Russian Foundation for Basic Research, grant 17-04-00360-OGN/ 19 2017-2019. 
a better command in these languages than in Frisian). This development shows that the dominating process (open > close contact) in the Germanic languages, which could be caused by the effect of the self-adjusting language system ensuring a better segmentation of the root morpheme in text, can be violated by a language contact. breaking.

Keywords: Frisian, correlation of contact, prosodics, vowel shortening, new Frisian

The present paper is a follow-up to my papers about the shortening of long consonants and long stressed vowels and the change of the syllable structure in the West Germanic languages and Danish [Kuz'menko 2017; 2018; 2019]. This time it will be about the change of the syllable structure and vowel shortening in Frisian.

\section{INTERPRETATION OF VOWEL QUANTITY IN FRISIAN}

Traditionally the vowel quantity in Frisian is considered to be phonologically relevant. This interpretation is based on the data of instrumental phonetics which show a clear difference in length between long and short vowels and on the possibility of a short vowel in monosyllabic CV-words [Fokkema, 1959, blz. 61; Cohen et al., 1959, blz. 108-109]. Fokkema does not give examples of such words but Visser, who wrote his $\mathrm{PhD}$ thesis on syllable in Frisian, describes them in detail. When he formulates a rule which he calls short vowel filter in Frisian permitting existence of only long vowels in CV-word, he mentions those few words which break the rule. These words are prepositions, pronouns and adverbs such as ho [hu] „how“, $s a$ [sa] „so", $t a$ [ta] „to“, se [sə] „she“, do [du] ,then“, $j y$ [jo] „you“, wy [vi] „we“, $h y$ „he”, $m y$ „me“ etc. [Visser, 1997, p. 173-175]. The number of such words in Frisian is small and judging by the Frisian twenty five - volume dictionary [Wurdboek, 1984-2011] all of them can have a stressed variant with long vowel. In this way these words in Frisian are not different from similar words with weak and strong variants in English ${ }^{1}$ [Johnes, 1957].

${ }^{1}$ The fact that Modern English is characterized by the correlation of contact is testified by the different syllable division. In open contact words the syllable is open, in close contact words the syllable boundary does not separate the postvocalic consonant from the preceding vowel. English phoneticians even claim that in close contact words the consonant completely belongs to the root syllable [cf. Wells, 1990; Johnes 1997, p. XIII]. 
Following Fokkema the relevance of vowel quantity in Frisian is suggested by modern authors [Bussmann, 2004]. Although Fokkema determines the relevance of vowel quantity in Frisian he according to Trubetzkoy, who proposed the correlation of contact in the Germanic languages [Trubetzkoy, 1939, S.196-198] ${ }^{2}$, ponders the possibility of correlation of contact in Frisian, with vowel length depending on the type of contact [Fokkema, 1959, blz. 60-61]. Though Fokkema tends to the relevance of vowel quantity he calls short vowels "covered" (Dutch gedeckt) and long vowels "uncovered" (ongedekt) [Fokkema, 1959, blz. 60], which indicates the connection between vowel quantity and syllabic structure in Frisian, cf. traditional English terminology checked vowels - free vowels. The short "covered" (checked) vowels are vowels in a closed syllable, the long "uncovered" (free) vowels are vowels in an open syllable. Tröster, who described the disappearing East Frisian vernacular of Saterland also suggests vowel quantity as a distinctive feature [Tröster, 1996, S. 181-185], but he admits that in the words with the short high vowels, that is with the originally long vowels which have been shortened cf. /knipə/, OFr. knîpa "pinch“ or /brükə/, OFr. brûka "use", the perception of vowel shortness can be provided by the close contact [Tröster, 1996, S. 190].

The main problem of segmental prosodics of the Frisian as well as the segmental prosodics of the other modern West Germanic languages is the syllabification in disyllabic words with short vowels, cf. Fr. bidde /bidə/ „to pray“, dolle/dolə/ „to dig“, bigge/bigə/ „pig“, finne/finə/ „pasturage“, frette /fretə/ „to eat (about animals)“, gripe /gripə/ „to catch“, hoanne/hwanə/ „cock“, hjitte /hjitə/ „to be named“, libben /libən/ „life“, sekken /sekə/ „sacks“, stiennen/stjinən/ „stones“ etc. Examining the syllable division in Frisian Visser, according to the postulates of generative phonology, proposes two levels of syllabification. On the first level (initial syllabification) all Frisian syllables are closed regardless of vowel quantity (CV(:)C-V). cf. e. g. sekken (sck-)(ən) „sacks“, kranen (kra:n-) (ən) „stop-cocks“, tsjillen (tsjıl-)(ən) „wheels“, but on the surface level every syllable is converted into an open one (CV-CV), cf. sekken (se-) (kən), kranen (kra:-)(nən), tsjillen (tsji-)(lən) and every morpheme-fi-

${ }^{2}$ According to Trubetzkoy the correlation of contact (Silbenschnitt, Anschluss) is connected with the type of contact (close or open) of a vocalic syllable nucleus with the following consonant. The vowel length is consequently phonologically not relevant and depends on the type of contact [Trubetzkoy, 1939, S. 197] 
nal consonant turns to syllable initial one [Visser, 1997, p. 278]. However, neither the generalization of closed syllables on the deep level nor the opened syllables on the surface level reflects the real syllabification in Frisian. The treatment of the syllables in words with short vowels as closed in Frisian (cf. [Sipma, 1913]) indicates that the syllable division in Frisian is not different from the syllable division in the other West Germanic languages (closed syllable after a short vowel vs. open syllable after a long vowel). Thus, the correlation of syllable contact can be proposed also for Frisian. As main phonetic correlates of this correlation can be considered the distribution of vowel intencity [Spiekermann, $2000 ; 2004$ ] and vowel quantity. The crucial point in the correlation of contact is however the syllabification. The vowel shortening in this case indicates the change of the contact type (open > close).

If we use the traditional pattern of syllable structure with syllable initial, nucleus and coda we can propose two types of syllables in Frisian:

\section{Initial nucleus coda initial of}

nucleus

the $2^{\text {nd }}$ syll.

\begin{tabular}{|c|c|c|c|c|c|c|}
\hline \multirow{2}{*}{$\begin{array}{l}\text { Position N } \\
\text { open contact }\end{array}$} & 1 & 2 & 3 & l & 4 & 5 \\
\hline & C & $\mathbf{V}$ & V & l & C & $\mathbf{V}$ \\
\hline \multirow{3}{*}{ closed contact } & $d$ & $o$ & $o$ & l & $g$ & ə doge "to be good“ \\
\hline & C & $\mathbf{V}$ & $\mathrm{C}$ & I & $\mathbf{0}$ & $\mathbf{V}$ \\
\hline & $d$ & $\boldsymbol{o}$ & $g$ & I & $\boldsymbol{0}$ & a dogge „bulldog“ \\
\hline
\end{tabular}

Metrically CVV- and CVC- are equal, which is reflected in different syllabification and in similar modern West Germanic reduction of unstressed vowels, which affects the words CVV-CV and CVC-V in similar way.

The peculiarity of the contact correlation in the Germanic languages is that as a rule the Germanic disyllabic words consist of a root (stressed syllable) and unstressed suffix. In open contact words the morpheme-final consonant is separated by the syllable boundary from the preceding vowel (the situation which is characteristic of all phonemic language). But in the close contact words, the syllable boundary does not separate the postvocalic morpheme-final consonant from the preceding vowel. This situation is similar with the situation in the syllabic languages, where a morpheme always coincides with the syllable (as e.g. in Chinese, Vietnamese etc.). By the ratio of syllabic and morphological boundaries the Germanic languages with the correlation of 
contact can be placed between phonemic languages and syllabic ones [Kuz'menko, 1991].

The correlation of contact was characteristic already of Old and Middle Frisian after the shortening of the long consonants ${ }^{3}$. And it is preserved in Frisian until now. But in the $17^{\text {th }}-18^{\text {th }} \mathrm{c}$. in Frisian we can observe the development which leads to vowel shortening and to the change of the contact type. The open contact turns into the close contact. This development which is spreading by lexical diffusion (word by word) corresponds to similar change in English and Danish (see [Kuz'menko, 2018; 2019]), but it has some pure Frisian peculiarities.

\section{POSITIONS OF VOWEL SHORTENING IN FRISIAN}

Even if the correlation of contact in general is similar in the West Germanic languages, there is considerable difference in its realization in various Germanic areas. In German and English as a rule there is no alternation of the contact type in the same root morpheme cf. Germ. Lamm - Lämmer - Lammbraten, but lahm - lahme - lahmen - Lahmheit. Only in few cases we can observe facultative alternations of close and open contact in some English words, cf. room /ru:m/ /rom/, poof /pu:f/ /pof/, poofy/pu:fi/ /pvfi/, stook/stu:k/ /stok/ [Johnes, 1997]. More often an alternation of contact type in the same root morpheme can be found in Dutch and Low German, though even there the lack of alternation is a rule (see below for more detail). In the West Frisian the alternations of contact type in various grammatical forms occur very often. The monosyllabic forms preserve as a rule an open contact, whereas in the bisyllabic forms the open contact is converted into the close one. In Standard West Frisian the conversion and the vowel shortening occur in the following cases $\left.{ }^{4}: 1\right)$ in plural forms of the nouns $\mathrm{cf}$. sg. faam /fa:m/ „girl“ - pl. fammen /famən/, sg. mûs /mu:s/ „mouse“ - pl. mu-

${ }^{3}$ Criticism of the hypothesis about the ambysyllabisity of consonants in modern West Germanic languages in words like Germ. fallen, bitte see [Kuz'menko, 2017]. Only in the eastern Frisian dialect of Wangerooge in the early $19^{\text {th }} \mathrm{c}$. the long consonants of Swedish-Norwegian type with the second syllable initial part were preserved (see lit. in [Kuz'menko, 2017]).

${ }^{4}$ Examples here and in the other cases are taken from the Frisian dictionary [Wurdboek, 1984-2011] and from various descriptions of Frisian, cf. [Siebs, 1901; Sipma, 1913; Graaf de, Tiersma, 1980; Tiersma, 1983; Graaf de, 1985; Meer van der, 1985]. The transcription of the authors is preserved. 
zan /muzən/, sg. stien /sti.ən/ „stone“ - pl. stiennen /stjinen/, sg. beam /bi.əm/ „tree“ - pl. beammen /bjemən/, sg. foet/fu.ət/ „foot“ - pl.fuotten /fwotən/, sg., boerd /bu·ərd/ „board“ - pl. bworden /bwordən/, sg. soan /so.ən/ „son“ - pl. swannen /swanən/ etc.; 2) in comparative and superlative forms of adjectives (fier/fr.orn/ "far" - firner/ffirnor/, moai /mo·i/ „beautifull“, - moaier /mwaiər/, swier /sviər/ „heavy“- swierst /svjirst/ superl.; 3) in diminutive forms of nouns (cf., stien - stjintse, stjinke "little stone“, boerd - bwordtje "little board“, soan - swantse, / swanke "little son“, wiif /vi:f/ — wyfke /vifkə/ „little woman“, faam /fa:m/ - famka /famkə/ „little girl“ -laem /la:m/ — lamke /lamke/ „little lamb“, knoop /kno:p/ - knoopke /knopkə/ „little button“, mûs /mu:s/ — múske /myskə/ „little mouse, little boy“, beam /bı·əm — beamke /bjemkə/ „little tree“ etc.; 4) in words with several derivative suffixes (suffixes of nouns -ing, -ling, -sel, -skip, -ster, -te cf. keat /kI.ət/ „link“ keatting /kjetin/ „chain“, bliid /bli:t/ "glad“ - blytskip /blitskip/ „gladness“, beam /bi·əm/ „tree“ - beamte /bjemtə/ „trees, (collective)“; adjectives -lik, -ich, -sk, cf. /ti:t/ „time“ - tydlik/tidlək/ „temporal“, bloed /blu·ət/ „blood“— - bloedderich/blwodrəx/ „bloody“, niid/ni:t/ „envy“— nidich /nidəx/ „angry“, keal /kr·əl/ „calf“- kjellich /kjeləx/ „young and silly“; verbs -kje, -je, -te, cf. loai /lo·i/ „lazy“ - loaikje /lwaikjə/ „to be lazy“, lape /la:pə/ "patch“ - lapje /lapjə/ „to patch“; 5) as a rule an open contact is converted into a close one when a word becomes a component of an compound cf, beam /br.əm/ „tree“ - bjemtûke /bjemtu:kə/ „branch“, earm /I·ərm/ „poor“ - jernmolde /jenmo:də/ „poverty“, hea

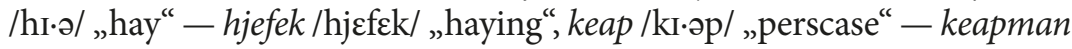
/kjepmon/ „merchant“, hûs /hu:z/ "house“ - húsman /hysmon/ „husbandman“, hústek/hystek/ „roof“, húshalde /hyshə:də/ „to keep house“ etc.

In monosyllabic words the change of contact and vowel shortening is typical of the words with original long high vowels (or of the original short high vowels lengthened in Middle Frisian), cf. ryk/rik/ OFr. rîk „rich“, ryp /rip/, wyn /vin/, OFr. wîn „wine“, skyn /skin/ or skjin, OFr. skîn „light“, fjild /fjilt/, OFr. feld (> MFr. /fe:ld/) „field“, bûk/buk/, OFr. bûk, bûch „stomach“, brún /bryn/, OFr. brûn „brown”, tún/tyn/ OFr. tûn "garden“, djip /djip/ OFr. diāp „deep“, hoek/huk/ „hook“ OFr. hôk, hoep /hup/ "hoop“ OFr. hôp etc. The contact change and the vowel shortening occur also in two-syllable words which are not forms of monosyllabic words, cf. tsjinje /tsjinə/ „serve“, hjitte /hjitə/ „to be called“, reamme /rjemə/ „cream“, ljedder/ljedər/ „ladder“, hoanne/hwanə/ „cock“ etc. In 
some words the old form with open contact and long vowel optionally alternates with the new form with close contact and vowel shortening, cf. doek /du:k/ /duk/ „linen“, broek /bruk/ /bru:k/5 „trousers“, boek /bu:k/ /buk/ „book“, siik/si:k/ /sik/ „ill“, roet/ru·ət/ /rwot/ „soot“, spoen /spu·ən/ /spwon/ „chip“. However, not all originally long vowels were shortened. Many words an preserve open contact and long vowel quantity, cf. OFr. îs, WFr. iis /i:s/, Saterl. ies; OFr. hûs - WFr. hûs /hu:s/, Saterl. huus, OFr. hopia „hope“, WFr., Saterl. hoopje etc.

Different Frisian dialects show different degree of vowel shortening. Most of all the change of the contact type is characteristic of the West Frisian continental dialects. To a much lesser extent, this change has affected the dialects of Schiermonnikoog and Hindeloopen and the East Frisian dialect of Saterland (Germany). In Saterland, the only place where the East Frisian dialect is still preserved, in many cases both monosyllabic and bisyllabic words which have shortened vowels in West Frisian, are not affected by this change, cf. OFr. tûn "garden“, bûk „stomach“, thûme „thumb“, lîne „linen“, bîte „bite“, bôk „book“ - Saterl. buuk, tuum, tuun, liene, biete, bouk [Fort, 1980, p. 55-58], cf. West Frisian tún/tyn/, tûme/tumə/, bûk/buk/, boek/bu:k buk/, bite/bitə/, line /linə/. The Middle Frisian long vowels which developed from the Old Frisian short ones before some consonant groups have also preserved their quantity in Saterland but they have been shortened in West Frisian (OFr. bild "picture“, binda „to connect", wind „wind", hund „dog“ Saterl. bield, biendo, wiend, huund (ibid.), but WFr. byld /bilt/, bine /binə/, wyn /vin/, hûn /hun/.

In Schiermonnikoog original long vowels were shortened only before voiceless consonants; before voiced consonants the long vowels preserve their quantity and open contact, cf. /ryt/ „window-plane“ (< MLG rûta), /slytə/ "to close“, krypə/ „to creep", /dykə/ „to dive“, /rykə/ „smoke“, /brykə/ „to use“ etc, but / glïdə/ „to glide”, /rìdə/ „to ride“, /sīdə/ „1. side, 2. silk“, sȳgə „to suck“, bȳgə/ „to bow“. In the Standard West Frisian as a rule the high vowels were shortened before the voiced consonants (cf. /sidə/), though some words have optional variants with long vowels, cf. /glidə/ /glidə/, /ride/ /rīdə/). The shortening of the

5 The Frisian dictionary notes that the pronunciation /bru:k/ with a long vowel is obsolete in the Standard West Frisian [Wurdboek, 1986, Bd. 3, S. 229]. The dialects of Schiermonnikoog and Hindeloopen preserve a long vowel in this word [Wurdboek, 1986, Bd. 3, S. 229]. 
high vowels is also typical of Northern Frisian dialects, cf. rik „,rich“, wit „wide“, swin „pig“, wis „wise“, is „ice“, skriwe „write“, bite „to bite“, hus „house“, bruke „to use“ [Siebs, 1901, S. 1162, 1220, 1225]. In the North Frisian continental dialect of Bökingharde we can observe not only the general shortening in is, tid, lik, gripe, knif, wid, brün, brüke, rüm, hüs, dün, wüf, tün, säke, bäken, brädj, bök etc but also a secondary shortening of the new high vowels in some vernaculars, cf. lim "clay“, rik „smoke“, hùs „hoarse“, kùl „cabbage“, drùm „dream“, dùf „deaf“, lùpe "to run“, rùk „stack“ etc [Walker, 1980, vocabulary]. In these vernaculars a new qualitative vowel opposition developed in close contact words (rik „rich“ - rik „smoke“, hus "house“- hùs „hoarse").

\section{POSSIBLE PRECONDITIONS FOR VOWEL SHORTENING IN FRISIAN}

The vowel shortening and the change of the contact type (open > close) in Frisian can be compared with similar development in the other West Germanic languages and Danish, where approximately since the $15^{\text {th }}$ century the shift of the syllable boundary and the vowel shortening can be observed. This change leads to the increased number of close contact words with the coincidence of syllable with morpheme. This development is spreading by lexical diffusion starting at the most convenient phonetic positions and covering little by little more and more new words. In Frisian the vowel shortening starts in the words with high vowels before voiceless stops and in disyllabic words earlier as in monosyllabic ones. However, the phonetic dependence of vowel duration on vowel height and on the quality of the following consonant is a general phonetic rule which is valid at all times and in all languages, so they can not be considered reasons for changes. According to the concept of the language as a self-adjusting system which can change itself to achieve a certain goal (cf. e.g. [Mel'nikov, 1966]) we can propose what for the syllabic structure changes and the vowels shorten. This change in Frisian as well as similar development in the other West Germanic languages occurs to indicate the boundaries of the root morpheme which in the great majority of close contact words began to coincide with the syllable. At first stage the speakers choose realizations which are best suited to this task. Phonetically shorter vowels are reinterpreted as indicators of the closed contact which results in the shift of the syllable boundary. The 
close contact and vowel shortening spread later to other positions increasing the number of words with the coincidence of syllable and morpheme. The vowel shortening in bisyllabic words $\mathrm{CV}$ :-CV prevents the separation of the morpheme-final consonant from the preceding root vowel providing coincidence of the root vowel with syllable. Most clearly the connection of the closed contact with morphology in Frisian is indicated by the rule that an open contact word changes the type of contact (open > close) when it becomes a part of a compound (see above).

\section{NEW FRISIAN BREAKING}

The Standard West Frisian differs from some other Frisian dialects as well as from the other West Germanic languages thereby that the change of the contact type and vowel shortening in words with the falling diphthongs $/ \mathrm{i} \cdot \partial /, / \mathrm{I} \cdot \partial /, / \mathrm{o} \cdot \partial /, / \mathrm{u} \cdot \partial /$ have a special form. When shortened these diphthongs become not only short but even rising, cf. /i.ə/ $>/ \mathrm{jI} /$ (stien /sti.ən/ - stiennen /stjinen/ pl.), /I.ə/ > /je/ (beam /bi.əm/ - beammen /bjemən/ pl.), /u.ə/ > /wo/ (foet /fu.ət/ - >fuotten /fwotən pl.), /o.ə/ > /wa/ (soan/so.ən/ - swannen/swanən/), further examples see above. This phenomenon which is called "new Frisian breaking" is found in most of the mainland West Frisian dialects and in the West Frisian standard. De Graaf and Tiersma assume that the new breaking corresponds functionally to shortening [Graaf de, Tiersma, 1980, p.119]. In some East and North Frisian dialects, where the long falling diphthongs were also shortened, the result of this shortening is a short monophthong [Graaf de, Tiersma 1980; Meer van der 1985, p. 17]. In the Frisian dialects with breaking every Old Frisian half-narrow vowel can have two reflexes (/e:/ > /iə/, /ji/, / $\varepsilon: />/$ Iə/, /je/, /o:/ > /uə/, /wo/, /o:/ > / oə/, /wa/) - [Tiersma, 1983, p.60]. The new Frisian breaking is considered to be the most important feature that distinguishes New Frisian from Old Frisian [Miedema, 1958, S. 148] . $^{6}$.

It is considered that short rising diphthongs in Modern Frisian [ji], [je], [wo], [wa] are biphonematic combinations of $/ w /$ and $/ j /$ with vowels (cf. e.g. [Fokkema, 1959]. Fokkema suggested a biphonematic value even of the long diphthongs/iə/ (/i/ +/ə/), /ıə/, /uə/, /oə/ [Coetsem van

${ }^{6}$ Markey calls the new Frisian breaking "one of the most dramatic developments" [Markey, 1975, p. 182]. 
et al., 1959] $]^{7}$. However, the lack of the syllable and morpheme boundary between the components both of a long falling and of a short rising diphthong as well as the alternation of these diphthongs in the same morpheme testifies monophonematic value of the both types of diphthongs. Anyway by any interpretation a short rising diphthong is associated with a close contact and a long falling diphthong with an open contact.

Although the alternation of falling and rising diphthongs occurs sporadically in Germanic languages ${ }^{8}$, the most accurate parallel to the new Frisian breaking is found in Danish Jutlandic dialects where the alternation regularly occurs also by the formation of plural, cf. Jutlandic /kuon/, standard Danish kone „woman“- /kwonər/ pl., /nies/ noese „nose“ - /nesər/ pl/, /puos/ pose „bag“ — /posər/ pl. (Bennike, Kristensen 1898-1912, 143), /dyən/ sb. sg. (dyne) „down“ - pl. /djønə/ (dyner), /muəs/ sb. sg. (mose) „moss“ - pl. /mwosə/ (moser) [Jensen, 1956, S. 53-75]. Nielsen notifies that in the vernacular of Bjerreherred (Eastern Jutland) in some cases the long diphthong /ie/ is hard to distinguish from /je/ or /jæ/, and the long diphthong /yø/ „almost everyone pronounces as /jø/“ [Nielsen, 1968, S. 51-52]. Just like in Frisian the long and short diphthongs can alternate facultative in some words, cf. /pwosə/ /puosə/ pl. „bags“ poser, /skwol/ - /skuol/ skole „school“ etc. [Nielsen, 1968, S. 52], /sdu'l/ — /sdwol'/ (stol) , /sdi'n/ — /sdjen'/ (sten), /su'l/ - /swol'/ (sol) [Bennike, Kristensen, ibid., 156]. The "stød" on consonant in Jutlandic forms like /sdwol'/, /sdjen'/ and /swol'/ indicates a superclose contact [Kuz'menko, 2018] and a complete coincidence of syllable and morpheme.

Similarity between the Frisian and Jutlandic development leading to the vowel shortening and change of the contact type (open > close) which increase the number of words with coinciding syllable and morpheme boundary is caused by the preconditions described above (dominating process (open > close contact) in the Germanic languages, which

${ }^{7}$ Van Coetsem considered that the question about phonological interpretation of both types of the diphthongs is not yet solved. According to him the diphthongs like [iə] and [jI] can be treated both as monophonematic and biphonematic units [Coetsem van, 1969, p. 167].

${ }^{8}$ Cf. English dialect forms [djed] $~[$ diəd] (dead), [bwə $\theta] \sim[$ buə $\theta]$ (both), [jek] [uək] (oak), [twəd] [tuəd] (toad). Sporadically such alternations are found in Low German, Dutch, Swedish and Norwegian dialects [Svensson, 1944, p. 87-89; 98-121; Kuz’menko, 1973, p. 191; Meer van der, 1985, p. 7-9]. 
is caused by the effect of self-adjusting language system ensuring a better segmentation of the root morpheme in text).

Such a development is characteristic of all the Germanic languages with the contact correlation. But the appearance of short rising diphthongs as prosodic variants of the long falling diphthongs, which to the extent is typical only of Frisian and Jutlandic must have a special reason. We can assume that the appearance of short rising diphthongs in Frisian and Jutlandic Danish is connected with the existence of the short rising diphthongs which developed in Proto Frisian and Proto Scandinavian (cf. OFr. riucht < ${ }^{*}$ reht „right", Mod.WFr. rjucht/rjoxt/; OFr. siunga < ${ }^{*}$ singwan "to sing“, Mod.Fr. sjonge /sjonə/, ODan. hiortoe < *herta"heart", Mod.Dan. hjerte, OSw. siunga < ${ }^{*}$ singwan, Mod.Sw. sjunga ${ }^{9}$. Short diphthongs of Proto Scandinavian and Proto Frisian breaking were preserved until the development of the contact correlation and in many cases they are preserved until now (see above). These short rising diphthongs of the new Frisian and Jutlandic breaking with the Proto-Frisian and Proto-Scandinavian breaking as well as the question whether the Frisian-Jutlandic similarity can be explained as the result of language contact requires more detailed study.

\section{VIOLATION OF VOWEL SHORTENING RULE IN THE MODERN WEST FRISIAN}

When we assume vowel shortening as a clear dominant feature in Frisian in the past few hundred years ${ }^{10}$, we have to answer the question why this development that was so dominant until recent time gives way to the generalization of open contact forms even in the disyllabic forms. Though the vowel shortening and the change of the contact type is characteristic of Frisian forms (cf. above) this alternation is not regular now and belong to lexicon, since in approximately $50 \%$ of forms this alternation does not exist and an open contact is preserved in disyllabic forms [Tiersma, 1983, p.63]. Respectively several disyllabic plural

${ }^{9}$ On the Old Frisian breaking see [Siebs, 1901, p. 1130; Heuser, 1903, p. 10-12; Boutkan, 1998, p. 80-83; Fort, 2001, p.404], on the Old Scandinavian breaking see [Noreen, 1913; Steblin-Kamenskiy, 1966; Kuz'menko, 1973].

${ }^{10}$ Ван дер Meep pointed out that vowel shortening "is a general Frisian trend" [Meer van der, 1985, p. 17] 
forms ${ }^{11}$ or diminutives preserve a long vowel and an open contact (cf. seal sg. /sr.əl/ „room“ - pl. sealen /sr.ələn/, spier /spi.ər/ "muscle“ pl. spieren /spi-ərən/, liet /li.ət/ "song“ - dimin. lietje /li.ətjə/, boer /bu.ər/ "farmer" - dimin. boerk /bu.ərk/; boat /bo.ət/ „boat" — dimin. boatse /bo·ətse/, /rr.ət/ adj. „red“ - /rr·ədər/ reader „more red“, but leaf /li.əf/ „loved“- ljevver „more willingly“; grien /gri.ən/ adj. „green“ griente /gri.əntə/ „to green“, but griente /grjintə/ „vegitables“, wier /wi.ər/ adj. „true“ - wierlik "truthfull“, but wierheid /wjIrheit/ „truth“. The above mentioned dissyllabic forms with long vowels and open contact have already penetrated the Standard West Frisian. In the language of the younger generation in the end of the $20^{\text {th }}$ century the standard forms with short vowel and closed contact (e.g. pl. stiennen /stjinən/ cf. sg. stien/stion/ -) are replaced by the non-standard forms like /stionən/ pl. [Graaf de, 1985, p. 30-31]. The forms with the prosodic pattern of dissyllabic plural forms coinciding with the prosodic pattern of monosyllabic forms are very often. The forms of diminutives appear to be more resistant to this change though even they can be used with a long vowel, cf. the non-standard form stientse "little stone" along with the "right" form /stjintsa/) - (Graaf de, 1985, p.29-30). What is the reason for productivity of this process in Modern West Frisian? The change short vowel > long vowel and close contact $>$ open contact in disyllabic forms contradicts the main trend of Modern West Germanic languages and Danish, where an opposite phenomenon and increased number of words with sort vowel and closed contact can be observed. It seems that the unification of open contact forms is caused not only by everlasting reason of analogy, but also (and probably first of all) by language contact and a special situation of the modern Frisian. At present time all the speakers of Frisian in the Netherlands and especially in Germany are at least bilingual and the young Frisian generation in the Netherlands not to mention Germany has a better command in the Netherlands [Breuker, 2001, p. 122] and German than in Frisian. The Frisian languages in the Netherlands in recent centuries has been strongly influenced by the Dutch ${ }^{12}$. If we pay attention to the formation of plural in

${ }^{11}$ Dammel and coauthors consider that vowel shortening in plural is not productive in Modern Frisian. The rule is the preservation of a long vowel [Dammel, Kürscher, Nübling, 2010, p. 612].

12 Breuker points out that "the influence of Dutch on Frisian is profound", and that and this influence will increase in the future [Breuker, 2001, p. 126], see also [Graaf de, 2016, p. 13]. 
Dutch we can see that the most productive pattern is the inflection -on and the preservation of the prosodic form of the root (the root with an open contact in singlular preserves it in plural), cf. Dutch deel /de:1/ "part" delen /de:lən/ pl., gave /ga:və/ "present" - gaven /ga:vən/ pl., jaar /ja:r/ „year" - jaren /ja:rən/ pl., hoop /ho:p/ „heap“- hopen /ho:pən/ pl., huis /høys/ "house“ - huizen /høysən/ pl., pees /pe:s/ "sinew“ - pezen /pe:zən/ etc. ${ }^{13}$. According to the same model the plural form is built in Low German ${ }^{14}$, which had a strong influence on the East and North Frisian dialects (cf. [Tröster, 1996; Fort, 1997]) ${ }^{15}$. In the last two centuries the influence of Standard High German on East and North Frisian became stronger. Though the vowel shortening and the change of the contact type is characteristic for some positions in Dutch and Low German ${ }^{16}$ these languages do not reach the same degree of morphosyllabismus as Frisian or Jutlandic Danish. Frisian is surrounded by the Germanic languages with no vowel shortening and no contact shift in disyllabic words (CV:CV). Thus the ousting of the form CVCV (closed contact) by the form CV:CV (open contact) in West Frisian can be dependent on West Frisian - Dutch, East- and North Frisian - Low German and now High German language contact.

In this way we can observe now the struggle of two contradictory forces in Frisian. The vowel shortening and the change open contact $>$ close contact which leads to coincidence of stressed syllable with the root morpheme from the one hand and replacement of closed contact by open contact in disyllabic words which violates the above mentioned development and can be explained by the influence of Dutch, Low- and High German on the other hand. These contradictory developments

${ }^{13}$ In Dutch there is a small group of nouns with different types of contact in singular and plural cf. dak /dak/ "roof“ - pl. daken /da:kən/, dag /dax/ „day“ — dagen / da:xən/, dal /dal/ „valley“ - dalen /da:lən/, skip /skip/ „ship - skepen /ske:pən/ etc. However, this type in Dutch is not productive. Anyway the plural form has a long vowel and an open contact.

${ }^{14}$ Cf. the forms dach sg. "day" - da:3a pl. in West Low German and dach sg. dä:ch in North Low German vernaculars [Grimme, 1910, p. 31, 63].

${ }^{15}$ In some areas Low German has replaced Frisian (cf. [Rogby, 1967]). An East Frisian substrate is found even in Middle Low German [Ahlsson, 1964].

${ }^{16}$ Cf. shortening of long /i:/, /u:/, /y:/ in words like biet, boet, buut in Dutch and change of the contact type (open > closed) and respectively change of syllabification in words like gieten, futen and boeken which now have closed syllables and do not differ in syllabification from pitten, putten and pokken [Nootebom, Slis, 1972, p. 315]. The shortening of the narrow vowels (cf. /hus/ $</$ hu:s/, /tit/ $</$ ti:t) is also characteristic of Low German [Grimme, 1910]. 
show us that the dominating process which could be caused by the effect of self-adjusting language system (cf. [Mel'nikov, 1966]) can be violated by the language contact.

\section{REFERENCES}

Ahlsson L.-E. Studien zum ostfriesischen Mittelniederdeutsch. Uppsala: Boktryckeri Aktiebolag, $1964.96 \mathrm{p}$.

Bennike V., Kristensen M. Kort over de danske folkemål med forklaringer. Bd. 1-2, København: Gyldendal, 1898-1912. (Bd. 1 - 188 p., Bd. 2 -104 maps)

Breuker W. West Frisian in language contact. Handbuch des Friesischen. Hg. Von H. H. Munske. Tübingen: Max Niemeyer Verlag, 2001. P. 121-129.

Boutkan D. On labial mutation and breaking in Old Frisian. Amsterdamer Bieträge zur älteren Germanistik 49, 1998. P.77-88.

Bussmann K. S. Diphthongs in Frisian: a comparative analysis of phonemic inventories past and present. Heidelberg: Winter, 2004. $271 \mathrm{p}$.

Coetsem van, F. Nogmaals de morfonologie van het Fries. Studia Frisica in memoriam Prof. Dr. K. Fokkema 1898-1967 scripta. (Fryske Akademy N 332). Walters - Noordhoff n. v. Grins, 1969. P. 162-169.

Cohen A., Ebeling C. L., Eringa P., Fokkema K., Holk van A. G. F. Fonologie van het Nederlands en het Fries. s-Gravenhage: Martinus Mijhof, 1959. 147 p.

Dammel A., Kürschner S., Nübling D., Pluralallomorphie in zehn germanischen Sprachen. Kontrastive germanistische Linguistik. TeilBd. 2. Olms, Hildesheim et al., 2010. P. 587-642.

Fokkema K., De consonanten en klinkerphonemen in het Fries. Zeitschrift für Mundartforschung 27. Jg. No. 1, 1959. P.49-63.

Fort M. C. unter Mitarbeit von H. Dumsdorf. Saterfriesisches Wörterbuch mit einer grammatischen Übersicht. Hamburg: Helmut Buske Verlag, 1980. 229 p.

Fort M. C. Niederdeutsch als zweite Sprache der Saterfriesen. Friesische Studien III (NOWELE Suppl. Vol. 18). Odense University press, 1997. P. 83-112.

Graaf de T. Phonetic aspects of the Frisian vowel system. NOWELE, 1985, No. 5. P. 23-40.

Graaf de T. Dutch, Frisian and Low German: the state language of Netherlands and its relation with two Germanic minority languages. Pt. 1. Scandinavian Philology, 2016, vol. 14, issue 1. P. 3-17.

Graaf de T., Tiersma P. Some phonetic aspects of breaking in West Frisian. Phonetica 37, No. 3, 1980. P. 109-120.

Grimme H. Plattdeutsche Mundarten. Leipzig: G. J.Göschen'sche Verlagshandlung, 1910. $166 \mathrm{p}$.

Jensen E. Houlbjergmålet bojningslore. København: Schultz, 1956. p. 144.

Johnes D. An outline of English phonetics. $8^{\text {th }}$ ed. Leipzig: Teubner, 1957. 328 p.

Johnes D. English pronouncing dictionary. $15^{\text {th }}$ ed. Eds P. Roach, J. Hartman. Cambridge: Cambridge University Press, 1997. 559 p. 
Kuz'menko Yu. K. Diftongi skandinavskogo prelomleniya [The diphthongs of the Scandinavian breaking]. Lingvisticheskie issledovaniya 1972, pt. 2. Moscow: Institut yazykoznaniya AN SSSR, 1973. P. 185-198. (In Russian)

Kuz'menko Yu.K. Fonologicheskaya evoluciya germanskih yazykov [Phonological evolution of the Germanic languages]. Leningrad: Nauka, 1991.284 p. (In Russian) Kuz'menko Yu. K. Sokrashchenie dolgih soglasnyh v datskom izapadnogermanskih yazykah [Shortening of the long consonants in Danish and in the West Germanic languages]. Scandinavian Philology, vol. 15, issue 2, 2017. P.223247. (In Russian)

Kuz'menko Yu.K. Sokrashchenie iskonnyh dolgih udarnyh glasnyh v datskom yazyke [Shortening of original short stressed vowels in Danish]. Scandinavian Philology, vol. 16, issue 2, 2018. P. 255-276. (In Russian)

Kuz'menko Yu.K. Sokrashcheniye dolgih udarnyh glasnyh $\mathrm{v}$ angliyskom yazyke [Shortening of long stressed vowels in English]. Materialy XLVII mezhdunarodnoy nauchnoy filologicheskoy konferencii. St. Petersburg: Izdatel'stvo filologicheskogo fakul'teta, 2019. (in print) (In Russian)

Meer van der G. Frisian "breaking“, aspects of the origin and development of a sound change. Groningen: Stifting FFYRUG, Grins, 1985. $137 \mathrm{p}$.

Mel'nikov G.P. Morfologicheskiy stroi jazyka i sredstva slovorazgranicheniya [Morphological structure of a language and means of word delimitation]. Issledovaniya po fonologii. Moscow: Nauka, 1966. P.262-284. (In Russian)

Miedema H.T.J. De neuwfriese „breking“ en zein verspreiding. Taal en tongval, Jg. 10, 1958. P. 148-156.

Nielsen B. J. Et Bjerreherredsmål: udtrykssystemet i dialekten i Barrit, Klakring og As sogne. København: Akademisk Forlag, 1968. 323 p.

Noreen A. Geschichte der nordischen Sprachen. Strassburg: Verlag von Karl J. Trübner, 1913. 239 p.

Nooteboom S. G., Slis I.H. The phonetic feature of vowel length in Dutch. Language and speech, 1972, v. V, N 4. P.301-316.

Rogby O. Niederdeutsch auf friesischem Substrat. Die Mundart von Westerhever in Eiderstedt (Schleswig-Hollstein). Uppsala: Almquist \& Wiksells Boktryckeri Aktiebolag, 1967. 255 p.

Siebs Th. Geschichte der friesischen Sprache. Grundriss der germanischen Philologie. Bd. 1, Hg. Paul von H. Strassburg: Karl J. Trübner, 1901. P. 1152-1433.

Sipma P. Phonology and grammar of modern Westfrisian with phonetic texts and glossary. Oxford University Press, 1913. 175 p.

Spiekermann H. Silbenschnitt in deutschen Dialekten. Tübingen: Niemeyer, 2000. $239 \mathrm{p}$.

Spiekermann H. Silbenschnitt im Niederdeutschen. Jahrbuch des Vereins für niederdeutsche Sprachforschung. Jahrgang 127, 2004. P. 123-140.

Steblin-Kamenskiy M.I. Skandinavskoye prelomlenie [Scandinavian breaking]. Ocherki po diahronicheskoy fonologii skandinavskih yazykov. Leningrad: Izdatel'stvo LGU, 1966. P.39-49. (In Russian) 
Svensson J. Diftongering med palatalt förslag i de nordiska språken. Lund: Håkan Ohlssons bokktryckeri, 1944. $262 \mathrm{p}$.

Tiersma P. The nature of phonological representation evidence from breaking in Frisian. Journal of linguistics, 19, 1983. P. 59-78.

Tröster S. Phonologischer Wandel im Saterländischen durch Sprachkontakt. Jahrbuch des Vereins für niederdeutsche Sprachforschung. Jg. 1996, Bd. 119. S. 179191.

Trubetzkoy N.S. Grundzüge der Phonologie. (Travaux du Cercle linguistique de Prague 7). Prague, 1939.271 S.

Visser W. The syllable in Frisian. Fryske Akademy no. 839, 1997. 405 p.

Walker A. G. H., Die nordfriesische Mundart der Bökingharde (Zeitschrift für Dialektologie und Linguistik. Beihefte no. 33). Wiesbaden: Franz Steiner Verlag $\mathrm{GmBH}, 1980.382 \mathrm{~S}$.

Wells J. C. Syllabification and allophony. Studies in the pronunciation of English. A commemorative volume in honour of A. C. Gimson. Ed. by S. Rasmaran. Routledge, London, New York, 1990. P. 76-86.

Wurdboek fan de Fryske Taal. Fryske Akademy. De Tille Ljowert - Leeuwarden. Bd. 1-25. 1984-2011.

\section{Юрий Константинович Кузьменко \\ Институт лингвистических исследований РАН \\ СОКРАЩЕНИЕ ИСКОННЫХ ДОЛГИХ УДАРНЫХ ГЛАСНЫХ ВО ФРИЗСКОМ ЯЗЫКЕ}

Для цитирования: Кuzmenko Yu.K. Shortening of long stressed vowels in Frisian // Скандинавская филология. 2019. Т. 17. Вып. 1. С. 5-21. https://doi.org/10.21638/11701/spbu21.2019.101

Статья посвящена изменению слоговой структуры и сокращению гласных во фризском языке. В первой ее части обсуждается интерпретация длительности гласных, которая в отличие от традиционной трактовки как фонологически релевантного признака рассматривается в качестве явления, зависимого от типа контакта (долгий гласный $=$ свободный контакт, краткий гласный $=$ плотный контакт). Смена свободного контакта плотным контактом во фризском начинается в конце XVII века и продолжается до сих пор. Большинство двусложных слов во фризском, так же как и в других германских языках, состоят из корня и суффикса. Изменение типа контакта (свободный плотный) и сокращение гласного увеличивает количество слов с совпадением слоговых и морфологических границ. Данное изменение соответствует сходному изменению в английском, голландском и датском, но имеет некоторые фризские особенности. Это касается сокращения гласных в двусложных словах с суффиксами и нового фризского преломления (появления кратких восходящих дифтонгов из долгих нисходящих

* Работа выполнена при поддержке гранта Российского фонда фундаментальных исследований № 17-04-00360-ОГН / 19 2017-2019 гг. 
дифтонгов при смене контакта (свободный плотный). Указанные черты отличают фризский от других германских языков, но объединяют его с датскими диалектами Ютландии, где новое преломление характерно для тех же типов слов, что и во фризском языке. Появлению новых кратких восходящих дифтонгов во фризском и датских диалектах Ютландии способствовало, вероятно, существование кратких восходящих дифтонгов древнефризского и древнескандинавского преломления, которые сохранялись до изменения типа контакта и сохраняются частично до сих пор. Поставлен вопрос о том, не является ли это изменение следствием фризско-ютландского языкового контакта. Замена плотного контакта свободным в двусложных словах в речи молодого поколения может быть объяснена голландским, нижненемецким и верхненемецким влиянием (поколение молодых фризов даже в Нидерландах, не говоря уже о Германии, лучше знают эти языки, чем фризский). Это изменение свидетельствует о том, что доминантный процесс (свободный контакт > плотный контакт), характерный для всех германских языков, который мог быть вызван действием самонастраивающейся системы языка, обеспечивающей лучшую сегментацию корневой морфемы в речи, может быть нарушен языковым контактом.

Ключевые слова: фризский язык, корреляция контакта, проводник, сокращение гласных, новофризское преломление.

\section{Yury Kuzmenko}

Dr. Sci. in Philology, Professor, Institute for Linguistic Studies, Russian Academy of Sciences, 9, Tuchkov per., St. Petersburg, 199053, Russia

E-mail: jk7559873@gmail.com

\section{Юрий Константинович Кузьменко}

д-р филол. наук, проф., Институт лингвистических исследований РАН, Россия, 199053, Санкт-Петербург, Тучков пер., 9 E-mail: jk7559873@gmail.com 